\title{
Modeling of Heat and Moisture Transfer in Wood in Finish Drying by the Energy of a Microwave Field
}

- N. N. Grinchik,

- A. L. Adamovich,

- O. A. Kizina \&

- U. M. Kharma

Journal of Engineering Physics and

Thermophysics volume 88, pages35-41 (2015)

A physicomathematical model of heat and moisture transfer in drying materials in the region below the hygroscopicity limit, including also the heating by the energy of a microwave field, has been developed. The developed system of equations has been solved numerically for three cases of drying of a wooden plate: convective drying, drying by the microfield-field energy, and drying combining the above two methods, i.e., combined drying. Results of numerical calculations of the temperature, vaporpressure, and moisture-content distributions in the cross section of the plate at different instants of time, and also of the change in the average moisture content and temperature in the process of drying, have been presented. The calculation results have been analyzed; conclusions on the differences and distinctive features of convective, microwave, and combined heating and drying have been drawn.

\section{References}

1. 1 . 
A. L. Adamovich, Determination of the complex permittivity of wood in the microwave range, Vestn. Polotsk. Gos. Univ., Ser. C. Fundam. Nauki, No. 10, 37-43 (2005).

2. 2 .

N. N. Grinchik, Processes of Transfer in Porous Media, Electrolytes, and Membranes [in Russian], ANK Inst. Tepl. Massoobmena im. A. V. Lykova AN BSSR, Minsk (1991).

\section{Google Scholar}

3. 3 .

S. P. Kundas, N. N. Grinchik, I. A. Gishkelyuk, and A. L.

Adamovich, Modeling of the Processes of Heat and Moisture Transfer in Capillary-Porous Media [in Russian], ANK Inst. Tepl. Massoobmena im. A. V. Lykova NAN Belarusi, Minsk (2007).

\section{Google Scholar}

4. 4 .

I. V. Krechetov, Drying of Wood [in Russian], Lesnaya

Promyshlennost', Moscow (1980).

\section{Google Scholar}

5. 5 .

G. S. Shubin, Drying and Heat Treatment of Wood [in Russian], Lesnaya Promyshlennost', Moscow (1990).

\section{Google Scholar}

6. 6 .

I. V. Akulich, Thermodynamic Processes in the Drying Technology [in Russian], ANK Inst. Tepl. Massoobmena im. A. V. Lykova NAN Belarusi, Minsk (2002).

\section{Google Scholar}




\section{Affiliations}

1. A. V. Luikov Heat and Mass Transfer Institute, National Academy of Sciences of Belarus, 15 P. Brovka Str., Minsk, 220072, Belarus

N. N. Grinchik

2. Polotsk State University, 29 Blokhin Str., Novopolotsk, 211440, Belarus A. L. Adamovich \& O. A. Kizina

3. Belarusian State University of Informatics and Radioelectronics, 6 P.

Brovka Str., Minsk, 220013, Belarus

U. M. Kharma

\section{Corresponding author}

Correspondence to N. N. Grinchik.

\section{Additional information}

Translated from Inzhenerno-Fizicheskii Zhurnal, Vol. 88, No. 1, pp. 3742, January-February, 2015.

\section{Cite this article}

Grinchik, N.N., Adamovich, A.L., Kizina, O.A. et al. Modeling of Heat and Moisture Transfer in Wood in Finish Drying by the Energy of a Microwave Field. J Eng Phys Thermophy 88, 35-41 (2015). https://doi.org/10.1007/s10891-015-1165-y

- Received23 August 2014

- Published05 March 2015

- Issue DateJanuary 2015

- DOI https://doi.org/10.1007/s10891-015-1165-y

\section{Keywords}

- wood

- moisture content

- convective heating 
- microwave drying

- combined heating and drying 